\title{
In vitro antibacterial, antioxidant, and cytotoxicity evaluations of Musa paradisiaca cv. Sekaki florets from Sarawak, Malaysia
}

\author{
Muhammad Mirza Ariffin ${ }^{1}$, Heng Yen Khong ${ }^{1 *}$, Nyotia Nyokat ${ }^{1}$, Gee Moi Liew ${ }^{1}$, Ahmad Sazali Hamzah², Korawinwich \\ Boonpisuttinant ${ }^{3}$ \\ ${ }^{1}$ Faculty of Applied Sciences, Universiti Teknologi MARA, Sarawak, Malaysia. \\ ${ }^{2}$ Centre for Synthesis and Polymer Technology, Institute of Science, Universiti Teknologi MARA, 40450 Shah Alam, Selangor, Malaysia. \\ ${ }^{3}$ Thai Traditional Medicine College, Rajamangala University of Technology Thanyaburi, Thanyaburi, Thailand.
}

\begin{tabular}{l}
\hline ARTICLE INFO \\
\hline Received on: $22 / 09 / 2020$ \\
Accepted on: $15 / 03 / 2021$ \\
Available online: $05 / 05 / 2021$ \\
\\
\hline Key words: \\
Musa, florets, phytochemical, \\
antioxidant, cytotoxicity.
\end{tabular}

antioxidant, cytotoxicity.

\begin{abstract}
Despite their ethnomedicinal properties, the florets generated from banana cultivation have long been considered as unimportant and improperly utilized thus far. This study assessed the total phenolic and flavonoid contents and antioxidant activities, in addition to the antimicrobial and cytotoxicity potentials of different solvent extracts of Musa paradisiaca florets to uncover their unique potentials. The total phenolic and flavonoid contents and antioxidant activity were determined spectrophotometrically, and the antimicrobial activity was assessed by minimum inhibitory and bactericidal concentrations assays, while cytotoxicity was evaluated in vitro via 3-(4,5-dimethylthiazol-2-yl)-2,5-diphenyltetrazolium bromide reduction assay. The ethyl acetate fraction recorded the highest phenolic content of $481.53 \mathrm{mg}$ Gallic acid equivalent $/ \mathrm{g}$ extract and managed to scavenge the most 2,2-diphenyl-1-picrylhydrazyl radicals, while the highest flavonoids' content was obtained in methanol fraction $(0.5294 \mathrm{mg}$ Quercetin equivalent/g extract). There was a linear correlation established between the phenolic contents of the extracts and the antioxidant capacities. The extracts also demonstrated notable antimicrobial activities against all the bacteria tested. The ethyl acetate fraction exhibited moderate cytotoxicity against the DU-145 cancerous cells with an inhibitory concentration $\mathrm{IC}_{50}$ value of $37.94 \mu \mathrm{g} / \mathrm{ml}$, which was comparable to the commercial chemotherapeutic drug, 5-fluorouracil $\left(\mathrm{IC}_{50}=32.50 \mu \mathrm{g} / \mathrm{ml}\right)$. The assays conducted in this study suggested that the $M$. paradisiaca florets possessed substantial antimicrobial, antioxidant, and cytotoxicity potentials.
\end{abstract}

\section{INTRODUCTION}

Vegetables, fruits, and spices have been used extensively since the primitive days to cure and alleviate ailments such as diarrhea, headache, and nausea. From time to time, researchers have managed to identify, isolate, and extract compounds that exhibit therapeutic and medicinal properties from various parts of plants such as tannin, ascorbic acids, and carotenoids. The advancement in science has enabled these compounds to be synthesized in laboratories on a large scale to be utilized in the medical and pharmaceutical industries. Nowadays, the increasing concern of health promotion has increased the demand for products containing functional components. It was found that agricultural

\section{"Corresponding Author}

Heng Yen Khong, Faculty of Applied Sciences, Universiti Teknologi MARA, Cawangan Sarawak, Malaysia.E-mail: khonghy@uitm.edu.my industry by-products contain several bioactive and functional compounds such as antioxidants, flavonoids, and anthocyanins (Sitthiya et al., 2018).

Generally, banana plants of different species or varieties produce edible fruits with various tastes, sizes, colors, and other characteristics. The fruits are known to be an excellent reservoir of potassium which aids in maintaining muscle functions and preventing muscle spasms. Besides that, the fruits also contain vitamins such as $\mathrm{A}, \mathrm{B}_{6}, \mathrm{C}$, and $\mathrm{D}$ which when consumed will help in boosting the immune system and ensuring proper metabolic functions (Kumar et al., 2012). However, it is worth noting that the nutritional and medicinal properties of Musa spp. are not only limited to the fruits but also other parts such as blossoms, peels, roots, and seeds (Padam et al., 2014). Unfortunately, very few works have been conducted on the biological and chemical evaluations on Musa spp. blossoms as previous studies only focused on parts such as peels and pulps. 
The banana blossoms, for instance, have long been used traditionally to treat diabetes and asthma as well as malnourishment especially in infants (Das et al., 2020), while the juice from the male flowers was found to provide relief for stomach problems in people of different age groups (Elancheran and Jayamuthunagai, 2014). The rich saponin content of the blossoms could be beneficial in maintaining healthy cholesterol levels and boosting the immune system (Adeolu and Enesi, 2013). A previous study also revealed that the blossom could be effective in managing noncommunicable diseases due to its potential to suppress the angiotensin-Iconverting enzyme and $\beta$-glucuronidase (Acharya et al., 2016). Another study targeted among lactating career women who consumed lactogenic biscuits formulated with banana blossom flour revealed that there was an increase in expressed breast milk among the women (Nordin et al., 2019). The authors noted that this effect could be contributed by the galactagogue property of banana blossoms which elevated breast milk production in women. Despite possessing ethnomedicinal properties, due to the lack of exposure and knowledge, the blossoms or florets are often regarded as unimportant and discarded as agricultural waste. This drawback has limited the application of the blossoms to be used only as organic fertilizers in the plantations instead of being properly utilized to their full potentials.

In recent years, several studies have been undertaken in exploring the potential of the banana by-products to serve as the source of bioactive compounds and phytochemicals. A study by Padam et al. (2014), for example, has discovered antioxidants, namely, epigallocatechin and its derivatives, from the banana flowers. Antioxidants such as epigallocatechin have been accepted to exhibit antimicrobial (Nikoo et al., 2018), anticancer (Chen et al., 2020), neuroprotective (Singh et al., 2016), and chemopreventive capabilities (Du et al., 2012, Hussain and Ashafaq, 2018). It is also revealed that the Musa spp. blossoms serve as natural sources of valuable phytochemicals, especially flavonoids and terpenoids which are known to exhibit potent antioxidative properties (Mahmood et al., 2011). Although humans are equipped with built-in antioxidant mechanisms against cancer-causing free radicals damage, it seems to be beneficial to obtain extra antioxidants in the diet, especially from fruits and vegetables (Baskar et al., 2011).

Previous pharmacological studies on the blossoms of Musa spp. revealed that they possess antidiarrheal, antiulcerative, hypoglycemic, and hypocholesterolemia activities (Imam and Akter, 2011). The blossom extracts were also found to show cytotoxic and antiproliferative activities against several cancer cells such as human colon cancer cells, HT29, and HCT-116, as well as HeLa and breast cancer cells (Arun et al., 2018; Dahham et al., 2015; Nadumane and Timsina, 2014). However, despite the elaborate studies conducted to evaluate the pharmacological potentials of Musa spp. blossoms, there are still very few pieces of literature that are reported on the isolation of specific compounds responsible for the activities. Thus, more studies should be focused on targeting the compounds which could be developed into products of substantial medicinal importance. Even though synthetic materials are predominantly used in fields such as medical and pharmaceutical (Johnson, 2019; Velmurugan, 2018), there has been a growing interest in evaluating the potential of plants phytochemicals as alternatives to synthetic substances
(Cao et al., 2017; Francini-Pesenti et al., 2019; Kapinova et al., 2018). Since phytochemicals are found abundantly in plant tissues (Xiao and Bai, 2019), it would be worthwhile to explore more on the presence of phytochemicals in banana blossoms which are expected to exhibit beneficial properties.

While there are many published studies on the phytochemical analysis and biological assays of various Musa spp. varieties, there are very few studies on the chemical and biological evaluation of local Musa spp. in Sarawak. Thus, this study aims to assess the phytochemical constituents as well as the pharmaceutical potential of local Musa spp., particularly the Musa paradisiaca Sekaki variety.

\section{MATERIALS AND METHODS}

\section{Plant materials}

The fresh blossom of M. paradisiaca was collected from Banana Tree Sdn Bhd, Kuching, Sarawak, Malaysia. The blossom was first separated into the bracts part and the florets part. The florets $(4.535 \mathrm{~kg})$ were then cleaned and air-dried under adequate ventilation for 8 days at room temperature $\left(24^{\circ} \mathrm{C}-26^{\circ} \mathrm{C}\right)$. The dried florets were ground into a fine powder using an electric cutting mill. The ground sample was later stored in a vacuum storage bag before being further processing.

\section{Extracts preparation}

The $M$. paradisiaca florets powder (790 g) was first extracted with hexane by the maceration method for 24 hours at room temperature. The extract was filtered through Whatman No. 1 filter paper and the filtrate was concentrated in vacuo using rotavapor (BUCHI, R-200, Switzerland) to remove the solvent as well as moisture. The extraction process was repeated using various solvents, namely, chloroform, ethyl acetate, and methanol. The weights and yields percentages $(\% \mathrm{w} / \mathrm{w})$ of the crude extracts were $70.7 \mathrm{~g}(8.9 \%), 55.8 \mathrm{~g}(7.06 \%), 37.1 \mathrm{~g}(4.7 \%)$, and $41.4 \mathrm{~g}$ $(5.24 \%)$ for hexane, chloroform, ethyl acetate, and methanol extracts, respectively. All the extracts obtained were properly sealed in an airtight container and stored at room temperature before subjected to chemical and biological evaluations.

\section{Total phenolic content (TPC)}

The Folin-Ciocalteu (FC) colorimetric assay was chosen to measure the TPC of florets extracts by using the modified protocol originally reported by Singh and Aggrawal (2018) and Johari and Khong (2019). Samples with a concentration of $1 \mathrm{mg} / \mathrm{ml}$ each were initially prepared by dissolving $5 \mathrm{mg}$ of each extract in $5 \mathrm{ml}$ of methanol. The FC reagent was prepared beforehand by diluting one part of the reagent with 10 parts of deionized water (1:10). About $0.75 \mathrm{ml}$ of the reagent was combined and mixed with $100 \mu \mathrm{l}$ of each extract in a glass vial and the mixture was then allowed to equilibrate for 10 minutes at ambient temperature. $0.75 \mathrm{ml}$ of sodium carbonate $\left(\mathrm{Na}_{2} \mathrm{CO}_{3}\right)$ was added, and the mixture was shaken gently and incubated for 90 minutes at room temperature. The absorbance of the samples was then measured at $725 \mathrm{~nm}$ using UV-Vis spectrophotometer (Perkin Elmer, Lambda 25 , US) and compared to the gallic acid standard calibration curve $(0.2-1.0 \mathrm{mg} / \mathrm{ml})$. TPC was expressed as milligrams of gallic acid equivalents per gram of the extract. The TPC values of each extract 
were obtained based on the equation generated from the gallic acid calibration curve $\left(y=0.0004 \mathrm{x}-0.0163 ; R^{2}=0.9996\right)$ in Figure 1.

\section{Total flavonoid content (TFC)}

The aluminum chloride colorimetric method adapted from Chandra et al. (2014) was used to determine the flavonoid content in the extracts and quercetin was used as the standard. The stock quercetin solution $(1 \mathrm{mg} / \mathrm{ml})$ was prepared by dissolving $10 \mathrm{mg}$ quercetin in $10 \mathrm{ml}$ methanol and different concentrations of quercetin $(3.125-25 \mu \mathrm{g} / \mathrm{ml})$ were then prepared by serial dilution. The extracts $(1 \mathrm{mg} / \mathrm{ml})$ were also prepared by dissolving the extracts in methanol. $2 \mathrm{ml}$ of the standards or the extracts was then mixed with $2 \%$ aluminum chloride and incubated at room temperature for 60 minutes. The absorbance of the standards and all the extracts was measured at $420 \mathrm{~nm}$ using a UV-Vis spectrophotometer (Perkin Elmer, Lambda 25, US). The quercetin calibration curve $\left(y=0.0642 x+0.0335 ; R^{2}=0.9996\right)$ obtained in Figure 2 was then used to calculate the TFC in each extract. The

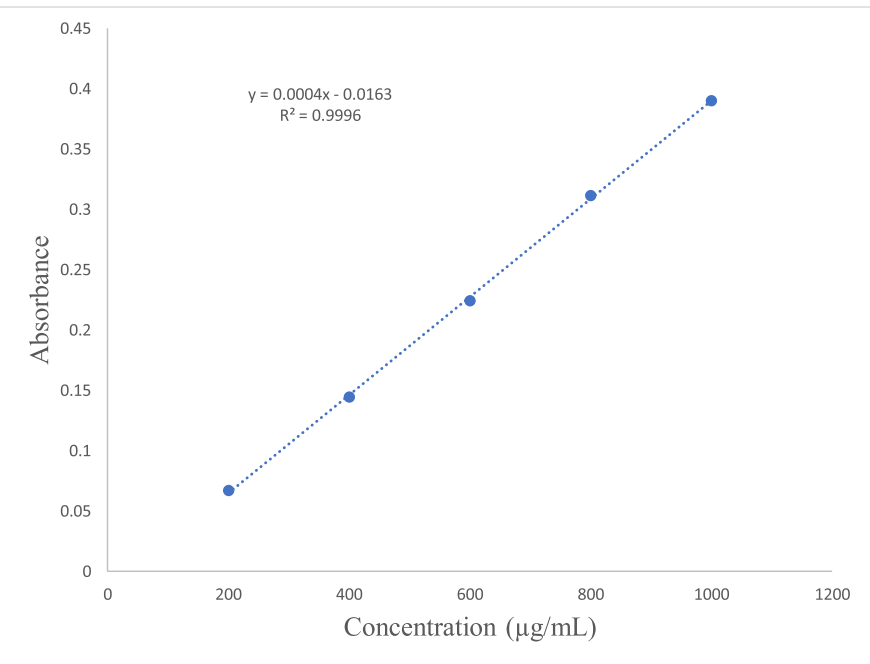

Figure 1. Standard calibration curve of gallic acid.

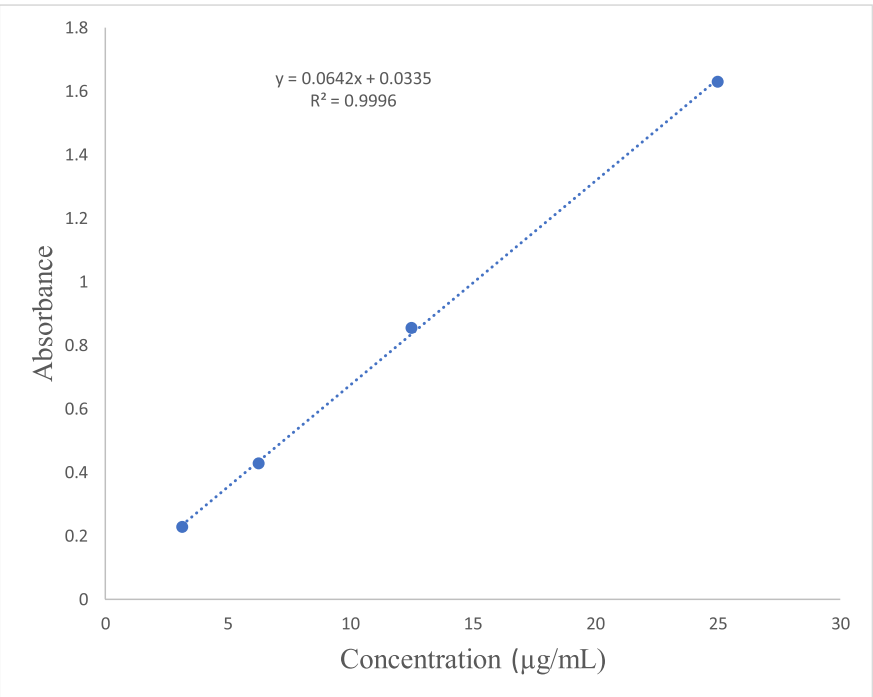

Figure 2. Standard calibration curve of quercetin. results were expressed as $\mathrm{mg}$ quercetin equivalents per gram of extract.

\section{2,2-diphenyl-1-picrylhydrazyl (DPPH) radical scavenging activity}

The scavenging activity of the extracts was evaluated by the spectrophotometric method adapted and modified from Pyrzynska and Pękal (2013). Ascorbic acid and absolute ethanol were used as the standard and working solution, respectively. The samples were prepared by dissolving the samples in absolute ethanol, followed by the addition of DPPH. The control was prepared by dissolving the DPPH in absolute ethanol. All the samples were vigorously shaken and incubated in the dark for at least 90 minutes at room temperature prior to analysis. The absorbance was measured in a UV spectrometer at $517 \mathrm{~nm}$. The radical inhibition activity was calculated using Eq. (1). A graph of percent inhibition of DPPH radicals (\%) against the concentrations of samples was plotted and the inhibitory concentration $\left(\mathrm{IC}_{50}\right)$ values were then calculated as follows:

Inhibition (\%)

$$
=\frac{\text { Absorbance of control }- \text { Absorbance of sample }}{\text { Absorbance of control }} \times 100
$$

\section{Antimicrobial assay}

Preparation of culture media

Nutrient agar (NA) and nutrient broth (NB) (Merck) were used as the culture media for the antimicrobial assays. Both media were prepared according to the manufacturer's directions and then sterilized at $121^{\circ} \mathrm{C}$ for 15 minutes in an autoclave. The media were allowed to cool at around $40^{\circ} \mathrm{C}$ before being used.

\section{Preparation of inoculum}

Two types of each Gram-positive (Streptococcus pyogenes and Staphylococcus aureus) and Gram-negative (Pseudomonas aeruginosa and Escherichia coli) microorganisms were prepared according to the method described by Johari and Khong (2019). The NB was used as the diluent and each of the organisms was inoculated into the diluent separately, and stored overnight at $40^{\circ} \mathrm{C}$.

\section{Minimum inhibitory concentration (MIC)}

This assay is generally used to determine the lowest concentration of a substance which inhibits the microscopically visible growth of microorganisms. The sample concentrations were used as the basis for the interpretation of the in vitro data. The stock solutions $(1,800 \mu \mathrm{g} / \mathrm{ml})$ were prepared in advance by dissolving $3.6 \mathrm{mg}$ of each extract in $2 \mathrm{ml}$ dimethyl sulfoxide (DMSO). The rows A and B of the 96-well plate were filled with the stock solution $(100 \mu \mathrm{g} / \mathrm{ml})$, while rows B-H were filled with sterile NB $(100 \mu \mathrm{g} / \mathrm{ml})$. The NB and sample at row B were well mixed and the mixture was shifted downward into each well from rows $\mathrm{C}$ to $\mathrm{H}$ to achieve a serial dilution by a factor of two $(1,800,900,450,225,112.5,56.25,28.13$, and 14.07 $\mu \mathrm{g} / \mathrm{ml}$, respectively). The inoculated bacteria $(100 \mu \mathrm{g} / \mathrm{ml})$ were then introduced into each well and the plate was covered with the lid, sealed, and incubated at $40^{\circ} \mathrm{C}$ for at least 24 hours. The base of the wells was later examined for any presence of pellets 
as well as changes in turbidity which signified the growth of microbes.

\section{Minimum bactericidal concentration (MBC)}

To revalidate the results from MIC, MBC assay, which represents the concentration capable of killing up to $99 \%$ of bacteria, was carried out by observing the bacterial growth in the agar plates. Agar plates were prepared beforehand by dissolving NA powder in distilled water and the mixture was then autoclaved for 15 minutes at $121^{\circ} \mathrm{C}$. The lukewarm NA was later poured aseptically into sterile Petri dishes. A micropipette was used to transfer $20 \mu \mathrm{g} / \mathrm{ml}$ of the content of the first clear stage in the 96well plate from the previously conducted MIC assay onto the agar plate. A sterile cotton bud was then used to gently streak the agar surface and the Petri dish was incubated for at least 24 hours at $37^{\circ} \mathrm{C}$. The $\mathrm{MBC}$ result was interpreted by observing the growth of the bacteria on the agar plate. If no growth was observed, the $\mathrm{MBC}$ was interpreted to correlate with the MIC and if growth was observed, the MBC was interpreted as one step higher than the MIC instead. A substance or compound is deemed as bactericidal if both the MIC and MBC values are close to each other (Tripathi, 2013). Both the MIC and MBC of the extracts were compared to that of positive control, streptomycin sulfate, which is a commercially available as an water-soluble antibiotic.

\section{Cytotoxicity on cell lines by 3-(4,5-dimethylthiazol-2-yl)-2,5- diphenyltetrazolium bromide (MTT) assay}

The anticancer activity was tested by using the method adapted from Sumathy (2018). The DU-145 human prostate cancer cell lines and HeLa (human cervical cancer) cells were cultivated first in Dulbecco's Modified Eagle Medium, enriched with antibiotics and $10 \%$ fetal bovine serum in a 96 -well plate. Each of the wells was filled with $200 \mu \mathrm{l}$ of the cell suspension, sealed, and incubated for 24 hours at $37^{\circ} \mathrm{C}$ in a $5 \% \mathrm{CO}_{2}$ atmosphere to promote the formation of a confluent monolayer. The cells'

Table 1. TPC and TFC of different extracts of Musa paradisiaca florets.

\begin{tabular}{lcc}
\hline Extracts & $\begin{array}{c}\text { TPC } \\
(\mathbf{m g ~ G A E} / \text { g extract) }\end{array}$ & $\begin{array}{c}\text { TFC (mg Quercetin equivalent } \\
\text { (QE) /g extract) }\end{array}$ \\
\hline Hexane & $165.90 \pm 0.02^{\mathrm{a}}$ & $0.1625 \pm 0.03^{\mathrm{a}}$ \\
Chloroform & $333.03 \pm 0.02^{\mathrm{b}}$ & $0.2838 \pm 0.01^{\mathrm{b}}$ \\
Ethyl acetate & $481.53 \pm 0.01^{\mathrm{c}}$ & $0.3598 \pm 0.02^{\mathrm{c}}$ \\
Methanol & $180.90 \pm 0.04^{\mathrm{d}}$ & $0.5294 \pm 0.05^{\mathrm{d}}$ \\
\hline
\end{tabular}

Results are expressed as $\mathrm{mg} / \mathrm{g}$ means \pm SD for three measurements $(n=3)$. Means in columns with different subscripts (a-d) are significantly different (Tukey's test, $p<0.05$ ). monolayer in each well was exposed to various concentrations of extract and nurtured for 24 and 48 hours. Next, MTT $(5 \mathrm{mg} / \mathrm{ml})$ was added and the medium was incubated for another 4 hours at $37^{\circ} \mathrm{C}$. The medium was discarded, and the formazan crystal left was dissolved in $100 \mu \mathrm{l}$ DMSO. The absorbance was measured in a microplate reader at $570 \mathrm{~nm}$. The cytotoxicity was calculated using Eq. (2).

Percentage viability $(\%)=\frac{\text { Test optical density }}{\text { Control optical density }} \times 100$

The $\mathrm{IC}_{50}$ values of the extract against the cell lines at 24 and 48 hours were later determined. The assay was repeated by replacing the extract with chemotherapeutic drugs doxorubicin hydrochloride, cisplatin, and fluorouracil.

\section{Statistical analysis}

All the analyses (TPC, TFC, antioxidant activity, and cytotoxicity) were carried out in triplicate to minimize the error and the results are presented as mean \pm standard deviation $(n=$ 3 ). The data obtained (Tables 1-3) were subjected to one-way analysis of variance and the significant differences between the means in different samples were determined by Tukey's post-hoc test at $p \leq 0.05$ using Statistical Package for the Social Sciences for Windows (V.24). The correlation coefficient $\left(R^{2}\right)$ between the TPC and antioxidant activity of the extracts was calculated using GraphPad Prism for Windows (v 8.3.0) to determine their relationship.

\section{RESULTS AND DISCUSSION}

\section{Total phenolic content (TPC)}

The TPC results of different extracts of $M$. paradisiaca florets are shown in Table 1. The TPC for chloroform extract (333.03 $\pm 0.01 \mathrm{mg}$ Gallic acid equivalent (GAE) $/ \mathrm{g}$ extract) and ethyl acetate extract $(481.53 \pm 0.01 \mathrm{mg}$ GAE$/ \mathrm{g}$ extract) was higher compared to the TPC of methanol $(180.90 \pm 0.01 \mathrm{mg}$ GAE/g extract) and hexane (165.90 $\pm 0.01 \mathrm{mg}$ GAE/g extract). The TPC results correlated with the study on $M$. paradisiaca $\mathrm{L}$. (cv. Nendran) blossoms which demonstrated that the ethyl acetate fraction recorded the highest phenolic content $(21.52 \mathrm{mg} \mathrm{GAE} / \mathrm{g}$ extract) as compared with the other solvent fractions (Nisha and Mini, 2014). The TPC recorded in this study was also higher compared to that in the $M$. paradisiaca (cv. P. Rastali) variety from another Malaysia region with TPC of $68.65 \mathrm{mg} \mathrm{GAE} / \mathrm{g}$ of extract (Marikkar et al., 2016).

Table 2. Inhibitory concentration of Musa paradisiaca florets extracts against different types of bacteria $(\mu \mathrm{g} / \mathrm{ml})$.

\begin{tabular}{|c|c|c|c|c|c|c|c|c|}
\hline \multirow{3}{*}{ Sample } & \multicolumn{8}{|c|}{ Test organisms } \\
\hline & \multicolumn{2}{|c|}{ SA } & \multicolumn{2}{|c|}{ SP } & \multicolumn{2}{|c|}{ EC } & \multicolumn{2}{|c|}{ PA } \\
\hline & MIC & MBC & MIC & MBC & MIC & MBC & MIC & MBC \\
\hline Hexane & 450 & 450 & 450 & 450 & 14.07 & 14.07 & 28.13 & 28.13 \\
\hline Chloroform & 450 & 450 & 450 & 450 & 14.07 & 14.07 & 28.13 & 28.13 \\
\hline Ethyl acetate & 450 & 450 & 450 & 450 & 14.07 & 14.07 & 28.13 & 28.13 \\
\hline Methanol & 450 & 450 & 450 & 450 & 14.07 & 14.07 & 28.13 & 28.13 \\
\hline Streptomycin sulfate & 14.07 & 14.07 & 14.07 & 14.07 & 14.07 & 14.07 & 14.07 & 14.07 \\
\hline
\end{tabular}


Table 3. Cytotoxicity activities ( $\mathrm{IC}_{50}$ and SI) of Musa paradisiaca extracts and chemotherapeutic drugs against DU-145 and HeLa cell at 24 and 48 hours.

\begin{tabular}{|c|c|c|c|c|c|c|c|}
\hline \multirow{2}{*}{ Cell line } & \multirow{2}{*}{ Sample } & \multicolumn{2}{|c|}{$\mathrm{IC}_{50}(\mu \mathrm{g} / \mathrm{ml})($ cancer cell) } & \multicolumn{2}{|c|}{$\mathrm{IC}_{50}(\mu \mathrm{g} / \mathrm{ml})($ normal cell) } & \multicolumn{2}{|c|}{ SI (normal/cancer cell) } \\
\hline & & 24 hours & 48 hours & 24 hours & 48 hours & 24 hours & 48 hours \\
\hline \multirow[t]{6}{*}{ DU-145 } & Doxorubicin hydrochloride & $\begin{array}{c}94.62 \pm 18.03^{\mathrm{a}} \\
\text { (moderate active) }\end{array}$ & $0.74 \pm 0.11^{\mathrm{A}}$ (very active) & $145.25 \pm 17.38$ & $97.02 \pm 7.95$ & 1.54 & 131.11 \\
\hline & Cisplatin & $\begin{array}{c}70.10 \pm 3.04^{\mathrm{a}} \\
\text { (moderate active) }\end{array}$ & $6.30 \pm 0.29^{\mathrm{B}}($ very active $)$ & $103.94 \pm 59.55$ & $53.16 \pm 3.26$ & 1.48 & 8.44 \\
\hline & 5-Fluorouracil & NA & $32.50 \pm 8.30^{\mathrm{C}}$ (moderate active) & $>1,000$ & $263.47 \pm 155.31$ & $-*$ & 8.11 \\
\hline & $\begin{array}{l}\text { M. paradisiaca methanol extract } \\
\text { (MpM) }\end{array}$ & NA & NA & $>1,000$ & $>1,000$ & -* & $-*$ \\
\hline & $\begin{array}{l}\text { M. paradisiaca ethyl acetate } \\
\text { extract (MpEA) }\end{array}$ & NA & $37.94 \pm 9.28^{\mathrm{C}}$ (moderate active) & $>1,000$ & $800.63 \pm 150.77$ & -* & 21.10 \\
\hline & $\begin{array}{l}\text { M. paradisiaca chloroform extract } \\
\text { (MpC) }\end{array}$ & $\begin{array}{l}624.13 \pm 227.44^{\mathrm{b}} \\
\quad \text { (low active) }\end{array}$ & $723.12 \pm 33.04^{\mathrm{D}}$ (low active) & $519.39 \pm 29.66$ & $582.85 \pm 46.06$ & 0.83 & 0.81 \\
\hline \multirow[t]{6}{*}{ HeLa } & Doxorubicin hydrochloride & $\begin{array}{c}90.27 \pm 6.88^{\mathrm{ii}} \\
\text { (moderate active) }\end{array}$ & $1.87 \pm 0.13^{1}$ (very active) & $145.25 \pm 17.38$ & $97.02 \pm 7.95$ & 1.61 & 51.88 \\
\hline & Cisplatin & $\begin{array}{c}55.28 \pm 2.05^{\mathrm{i}} \\
\text { (moderate active) }\end{array}$ & $6.23 \pm 0.38^{\mathrm{II}}$ (very active) & $103.94 \pm 59.55$ & $53.16 \pm 3.26$ & 1.88 & 8.53 \\
\hline & 5-Fluorouracil & NA & $308.33 \pm 19.57^{\mathrm{III}}$ (low active) & $>1,000$ & $263.47 \pm 155.31$ & $-*$ & 0.85 \\
\hline & MpM & NA & NA & $>1,000$ & $>1,000$ & $-*$ & $-*$ \\
\hline & MpEA & NA & $859.42 \pm 343.06^{\vee}$ (low active) & $>1,000$ & $800.63 \pm 150.77$ & $-*$ & 0.93 \\
\hline & $\mathrm{MpC}$ & $\begin{array}{c}522.15 \pm 37.17^{\mathrm{iii}}(\mathrm{low} \\
\text { active) }\end{array}$ & $444.47 \pm 5.91^{\mathrm{IV}}$ (low active) & $519.39 \pm 29.66$ & $582.85 \pm 46.06$ & 0.99 & 1.31 \\
\hline
\end{tabular}

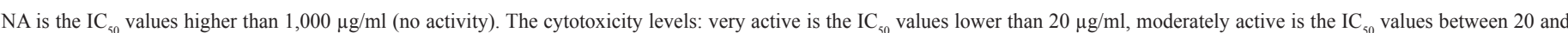

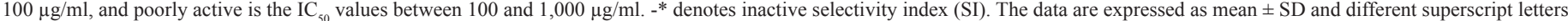
$\left({ }^{\mathrm{a}-\mathrm{b}}\right.$ and ${ }^{\mathrm{A}-\mathrm{D}}$ for DU-145 ${ }^{\mathrm{i}-\mathrm{iii}}$ and ${ }^{\mathrm{I}-\mathrm{V}}$ for HeLa) in the column indicate denote significant differences at $p<0.05$, Tukey's test.

The results obtained also portrayed that the differences in phenolic contents in M. paradisiaca florets extracts can be deduced to be dependent on the types of solvents used for extraction. Several studies have investigated the correlation of different solvents with the amount of phenolics extracted. Do et al. (2014) investigated the effect of various solvents on the phenolic contents extracted from Limnophila aromatica and found that the extract obtained by $100 \%$ ethanol showed the highest TPC. Another study by Han et al. (2016) showed that the ethyl acetate and acetone extracts of Ramaria botrytis recorded higher phenolic contents compared to the methanol and hexane extracts.

TPC assay is useful in determining the number of phenolic compounds in the plant samples. Phenolics have been the focus of many recent studies due to their antioxidative and free radical scavenging potentials (Agatonovic-Kustrin et al., 2018; Chandra et al., 2014). The ability of the phenolics to act as reducing agents by donating hydrogen and scavenging singlet oxygen in compounds gives rise to their antioxidant activity (Kruk et al., 2005; Sroka, 2005). Phenolics compounds are also found to prevent the peroxidation of lipids by inhibiting the action of several types of oxidizing enzymes such as lipoxygenases (Chandra et al., 2014; Khennouf et al., 2009). Generally, since higher phenolic content is associated with improved bioactivity, the ethyl acetate extract was expected to exhibit good antioxidant and antibacterial properties.

\section{Total flavonoid content (TFC)}

The ranges of the TFC values (Table 1) of the extracts are from $0.1625 \mathrm{mg} \mathrm{QE} / \mathrm{g}$ extract for hexane extract to 0.5294 $\mathrm{mg}$ QE/g extract for methanol extract and they decrease in the following order: methanol $>$ ethyl acetate $>$ chloroform $>$ hexane.
The trend observed in TFC was different compared to that in TPC, in which the TFC of the extracts increased with the increase of the polarity of the solvents used. However, the flavonoids' content obtained was relatively higher as compared to the values recorded in other M. paradisiaca flower varieties from Kuala Terengganu, Malaysia, with TFC ranging from $0.164 \mathrm{mg} \mathrm{QE} / \mathrm{g}$ extract to 0.25 mg QE/G extract (Us et al., 2016).

Flavonoids are one of the most studied subclasses of polyphenols which can be found in a variety of plants. They are found to possess unique properties such as anti-inflammatory, antiviral, restraining pathogenic bacteria, and protecting against ultraviolet radiation damage (D'Amelia et al., 2018; Han et al., 2016; Hwang et al., 2015). The polarity of extracting solvents used is crucial as it greatly enhances the solubility of various antioxidant compounds (Do et al., 2014; Muhamad et al., 2014). Hexane was found to record the lowest TFC which may be attributed to its nonpolar nature which inhibits its ability to dissolve polar molecules such as flavonoids. Our findings were supported by previous studies on Salacia chinensis (Ngo Van et al., 2017), Isatis tinctoria (Wakeel et al., 2019), and Zia mays L. (Nawaz et al., 2019) which signified that the extraction of flavonoids was improved in solvents with higher polarity.

\section{Antioxidant activity}

The results in Figure 3 show the DPPH inhibition activity by the $M$. paradisiaca florets extracts and standard at varying concentrations. The $\mathrm{IC}_{50}$ obtained for ascorbic acid was $15.33 \mu \mathrm{g} / \mathrm{ml}$, while each extract recorded $\mathrm{IC}_{50}$ values ranging between $38.26 \mu \mathrm{g} / \mathrm{ml}$ and $74.26 \mu \mathrm{g} / \mathrm{ml}$. Among all the extracts, the maximum antioxidant potential was observed in ethyl acetate $\left(\mathrm{IC}_{50}=38.26 \mu \mathrm{g} / \mathrm{ml}\right)$, followed by chloroform $\left(\mathrm{IC}_{50}=47.73 \mu \mathrm{g} / \mathrm{ml}\right)$ 


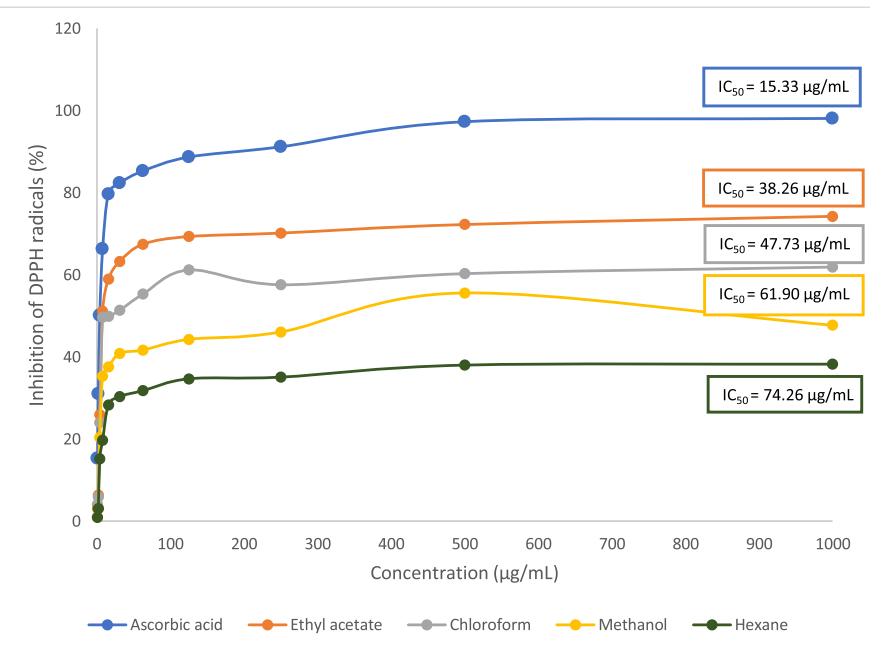

Figure 3. Antioxidant activity of different extracts of Musa paradisiaca florets. Each point represents mean \pm SD.

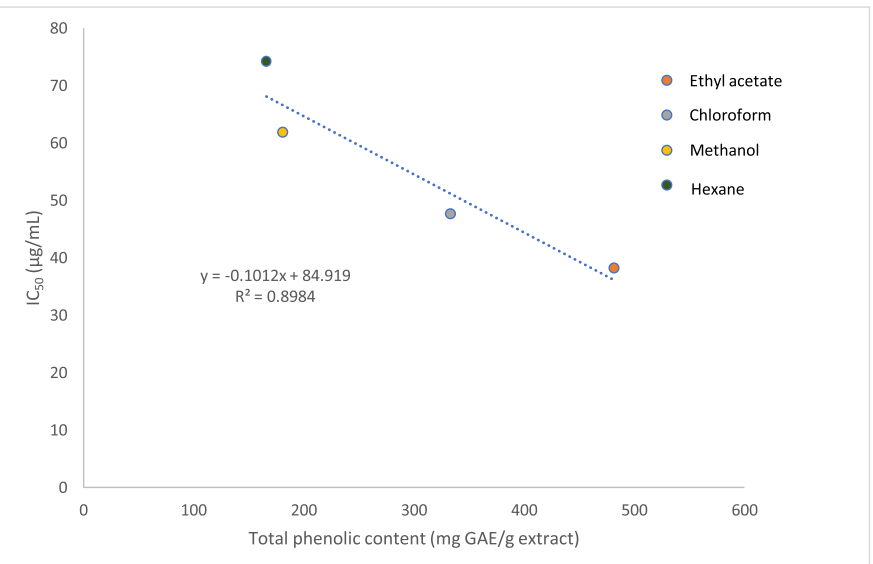

Figure 4. Correlation between TPC of Musa paradisiaca florets extracts and antioxidant activity by DPPH inhibition assay.

and methanol $\left(\mathrm{IC}_{50}=61.90 \mu \mathrm{g} / \mathrm{ml}\right)$, and it was lowest in hexane extract $\left(\mathrm{IC}_{50}=74.26 \mu \mathrm{g} / \mathrm{ml}\right)$. In comparison, the $\mathrm{IC}_{50}$ of the flower bract of M. paradisiaca variety in Iraq reported by Lafta (2020) was $168.04 \mu \mathrm{g} / \mathrm{ml}$, while another study by Joseph et al. (2014) on $M$. paradisiaca (AAB Nendran) floret extracts recorded $\mathrm{IC}_{50}$ ranging between $63 \mu \mathrm{g} / \mathrm{ml}$ and $242 \mu \mathrm{g} / \mathrm{ml}$. The variety of these $\mathrm{IC}_{50}$ values signifies that the antioxidative potential of banana florets is dependent on the region of cultivation as well as the cultivars of Musa species. On the other hand, the antioxidative property in this study showed a linear correlation with the phenolic content in the extracts $\left(R^{2}=0.8984\right)$ in which increasing phenolic content contributed to better antioxidant capacity (Fig. 4). The result correlates with a study by Pereira et al. (2015), which found that the antioxidative potential was dependent on the number of phenolic compounds present in the Byrsonima spp. plants.

DPPH is a stable free radical with a strong purple intensity which is widely used for the spectrophotometric measurement of antioxidant activity in plant extracts. Upon reduction by compounds through the transfer of electron or hydrogen, it undergoes discoloration and acquires a yellowish hue.
DPPH is preferred mainly due to its ability to detect the presence of active compounds even at low concentrations and short analysis time (Do et al., 2014). The low free radical inhibition potential shown by hexane may be contributed by the lack of polyphenolic compounds present in the extract. Plants' phenolics are known to exhibit strong antioxidant activity toward harmful free radicals due to their reducing character which gives them hydrogendonating property as well as singlet oxygen scavengers (Chandra et al., 2014).

\section{Antimicrobial activity}

The antimicrobial activity of $M$. paradisiaca florets against all the Gram-positive (S. aureus and S. pyogenes) and Gramnegative (E. coli and $P$. aeruginosa) bacteria were quantitatively and qualitatively assessed from the absence or growth of bacteria in both the MIC and MBC assays. Based on the MIC results in Table 2, all the extracts displayed an active inhibitory effect toward all the tested pathogens with values ranging from 14.07 to $450 \mu \mathrm{g} / \mathrm{ml}$. The extracts were highly potent against $E$. coli with MIC values comparable to that of streptomycin sulfate (14.07 $\mu \mathrm{g} / \mathrm{ml})$, followed by P. aeruginosa $(28.13 \mu \mathrm{g} / \mathrm{ml})$, whereas the weakest inhibition was observed in both $S$. aureus and $S$. pyogenes $(450 \mu \mathrm{g} / \mathrm{ml})$. The antibacterial property of the extracts was further extended to MBC assay and the data obtained correlated with the MIC assay in which the strongest inhibition was observed in E. coli, followed by P. aeruginosa, S. aureus, and S. pyogenes, respectively $(E$. coli $>$ P. aeruginosa $>S$. aureus $=S$. pyogenes $)$.

The MIC and MBC values are inversely proportional to the antibacterial property, in which lower concentrations signify stronger repressive activity. The results recorded are similar to the study reported by Jawla et al. (2012) which revealed that the $M$. paradisiaca flowers were potent against several pathogenic bacteria. Some of the bacteria used in this present study are commonly related to food-borne diseases, and since all the extracts showed inhibitory effect against these strains, this depicts that $M$. paradisiaca flowers could be utilized to suppress food-borne illnesses such as diarrhea and is a natural alternative to commercially available chemical preservatives used in food products.

\section{Cytotoxicity activity}

The cytotoxicity of the $M$. paradisiaca floret extracts on DU-145 cells (human prostate cancer), HeLa cells (human cervical cancer), and human dermal fibroblasts (normal cells) was investigated by MTT assay. Table 3 shows the cytotoxicity $\left(\mathrm{IC}_{50}\right.$ values) of the extracts on cancer cells, and Figure 1 shows \% cell viability of normal cells. The cytotoxicity of the floret extracts on DU-145 and HeLa cells was a time-dependent inhibitory effect. At 24 hours, the cytotoxicity on DU-145 and HeLa cancer cells was found only in the $\mathrm{MpC}$ extract with the $\mathrm{IC}_{50}$ values of $624.13 \pm 227.44 \mu \mathrm{g} / \mathrm{ml}$ and $522.15 \pm 37.17 \mu \mathrm{g} / \mathrm{ml}$, respectively. The activity was lower than doxorubicin hydrochloride $\left(\mathrm{IC}_{50}\right.$ for DU-145 of $94.62 \pm 18.03 \mu \mathrm{g} / \mathrm{ml}$ and $\mathrm{IC}_{50}$ for HeLa of $90.27 \pm$ $6.88 \mu \mathrm{g} / \mathrm{ml})$ and cisplatin $\left(\mathrm{IC}_{50}\right.$ for DU-145 of $70.01 \pm 3.04 \mu \mathrm{g} / \mathrm{ml}$ and $\mathrm{IC}_{50}$ for $\mathrm{HeLa}$ of $55.28 \pm 2.05 \mu \mathrm{g} / \mathrm{ml}$ ). At 48 hours, the MpEA extract showed the highest cytotoxicity on the DU-145 cells $\left(\mathrm{IC}_{50}\right.$ value of $37.94 \pm 9.28 \mu \mathrm{g} / \mathrm{ml}$ ), which was comparable to anticancer drug 5-fluorouracil $\left(\mathrm{IC}_{50}\right.$ value of $\left.32.50 \pm 8.30 \mu \mathrm{g} / \mathrm{ml}\right)$ but lower than doxorubicin hydrochloride $\left(\mathrm{IC}_{50}\right.$ value of $0.74 \pm 0.11 \mu \mathrm{g} / \mathrm{ml}$ ) 

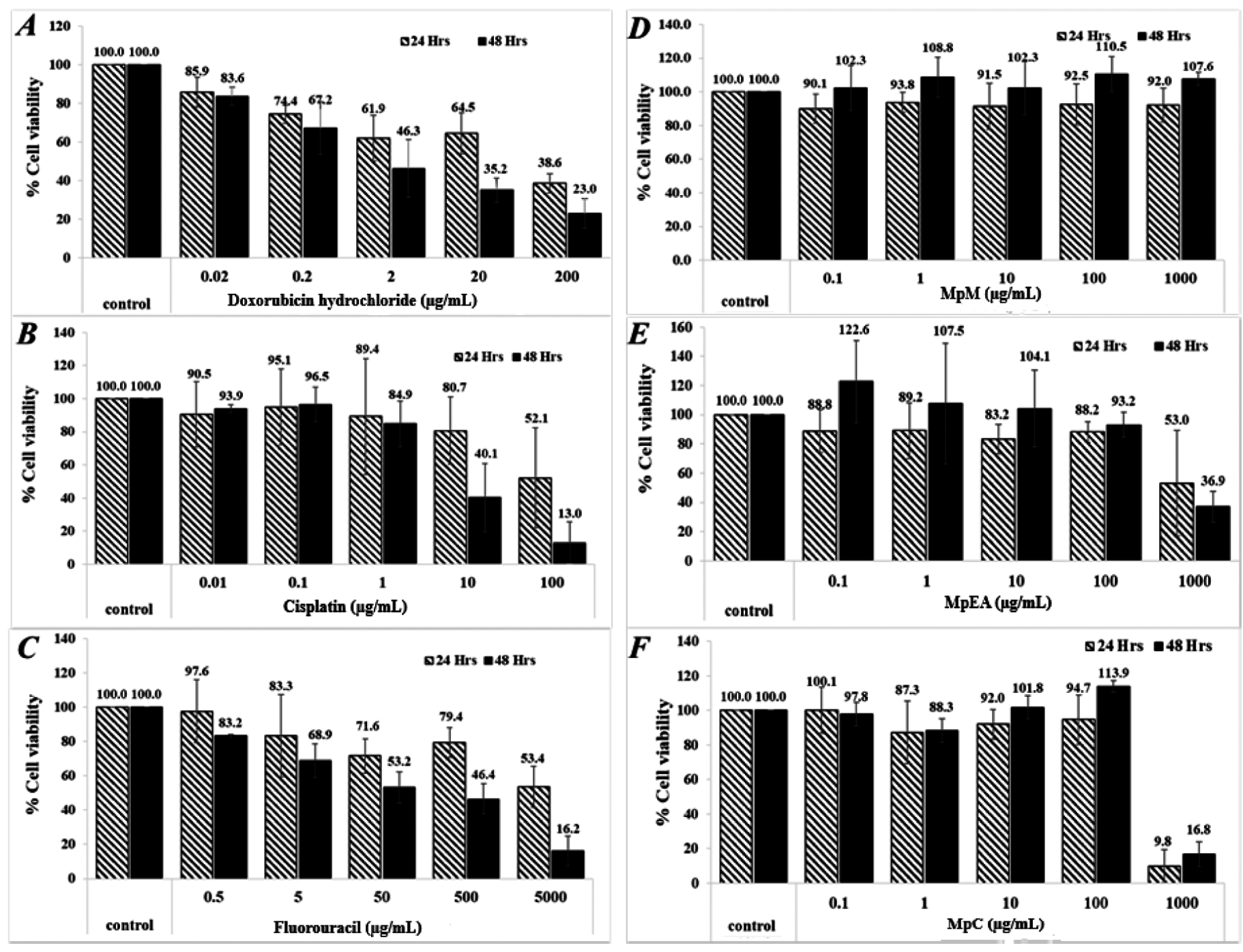

Figure 5. Cytotoxicity of Musa paradisiaca extracts and chemotherapeutic drugs against human skin fibroblasts at 24 and 48 hours. Doxorubicin hydrochloride (A), cisplatin (B), 5-fluorouracil (C), MpM (D), MpEA (E), and MpC (F).

and cisplatin $(6.30 \pm 0.29 \mu \mathrm{g} / \mathrm{ml})$, whereas the $\mathrm{MpC}$ extract showed the highest cytotoxicity on $\mathrm{HeLa}$ cells with the $\mathrm{IC}_{50}$ value of $444.47 \pm 5.91 \mu \mathrm{g} / \mathrm{ml}$, which were lower than anticancer drug including doxorubicin hydrochloride $\left(\mathrm{IC}_{50}\right.$ value of 1.87 $\pm 0.13 \mu \mathrm{g} / \mathrm{ml}$ ), cisplatin $\left(\mathrm{IC}_{50}\right.$ value of $\left.6.23 \pm 0.38 \mu \mathrm{g} / \mathrm{ml}\right)$, and 5 -fluorouracil $\left(\mathrm{IC}_{50}\right.$ value of $\left.308.33 \pm 19.57 \mu \mathrm{g} / \mathrm{ml}\right)$. The $\mathrm{MpM}$ extracts showed no cytotoxicity on both cancer cells. However, the activity of the MpEA extract on DU-145 at 48 hours was classified as moderate active $\left(\mathrm{IC}_{50}\right.$ of $\left.20-100 \mu \mathrm{g} / \mathrm{ml}\right)$, and the other extracts were classified as inactive compounds $\left(\mathrm{IC}_{50}>500 \mu \mathrm{g} / \mathrm{ml}\right)$ following the criteria of active compounds from National Cancer Institute (Tanamatayarat et al., 2003).

All extracts at the concentration below $100 \mu \mathrm{g} / \mathrm{ml}$ exhibited no cytotoxicity on human dermal fibroblasts (a normal cell) for 24 and 48 hours. The MpEA and MpC extracts at the concentration of $1,000 \mu \mathrm{g} / \mathrm{ml}$ for 24 and 48 hours showed cytotoxicity on human dermal fibroblasts (Fig. 5E and F), since they gave less than $80 \%$ cell viability when compared with the control (Buapool et al., 2013). Likewise, the anticancer drugs at low concentrations showed higher cytotoxicity on human dermal fibroblasts. In addition, the MpEA extract demonstrated the highest selectivity index (SI) of 21.10 on DU-145 cancer cell at 48 hours which was superior to cisplatin and 5-fluorouracil, whereas the $\mathrm{MpC}$ extract showed slightly lower SI on both cell lines.

MTT assay is generally implemented in colorimetric cytotoxicity evaluation by determining the survival rate of cells through the color change of yellow tetrazolium dye MTT to purple insoluble formazan crystal. The color change is induced by the reducing property of Nicotinamide adenine dinucleotide phosphate-dependent oxidoreductase enzyme in the active mitochondria of healthy cells. The intensity of the purple color formed is directly proportional to the enzymatic activity of the cells, in which the deeper purple color indicates a higher number of healthy living cells (Fatma Sri et al., 2015; Mosmann, 1983). The inhibitory effect demonstrated by the $M$. paradisiaca floret in this present study may be attributed by the presence of bioactive compounds in the extract, typically polyphenols and flavonoids which induce the apoptotic effect on 
cancerous cells. Bioactive compounds have long been shown to play a significant role in preventing the development of terminal illnesses such as cancer (Muniraj et al., 2019; Pan et al., 2009; Kris-Etherton et al., 2002). A previous study by Nadumane and Timsina (2014) also revealed that the ethanolic extract of $M$. paradisiaca flower managed to induce an antiproliferative effect on the HeLa cells with an $\mathrm{IC}_{50}$ value of less than $10 \mu \mathrm{g} / \mathrm{ml}$.

\section{CONCLUSION}

The findings from this study are evidence that $M$. paradisiaca cv. Sekaki florets exhibited high antioxidant and strong antimicrobial potentials as well as moderate cytotoxicity against the DU-145 human prostate cancer cell lines. Additionally, the higher phenolic and flavonoid contents are supported by the higher antioxidant property as compared to the cultivars used in the previous studies. The notable antioxidant and cytotoxicity performance depicted may be contributed by the presence of flavonoids and other phenolic constituents in the florets. However, the phytochemical constituents of the florets are dependent on the region of cultivation as well as cultivars of the Musa species. The florets which are a locally consumed functional food could be a potential antioxidant agent and could be used as a medicament against illnesses associated with free radical damages. Future studies are suggested to explore the vast medicinal values by assessing the in vivo biological activity as well as identify the phytochemical constituents to validate their pharmacological activities.

\section{ACKNOWLEDGMENTS}

We would like to acknowledge the Banana Tree Sdn. Bhd. Company (Malaysia) for granting permission to make the collections of banana blossom (M. paradisiaca cv. Sekaki) samples.

\section{AUTHOR CONTRIBUTIONS}

All authors made substantial contributions to conception and design, acquisition of data, or analysis and interpretation of data; took part in drafting the article or revising it critically for important intellectual content; agreed to submit to the current journal; gave final approval of the version to be published; and agree to be accountable for all aspects of the work. All the authors are eligible to be an author as per the international committee of medical journal editors (ICMJE) requirements/guidelines.

\section{CONFLICT OF INTEREST}

The authors report no financial or any other conflicts of interest in this work.

\section{FUNDING}

This work was supported by the Dana Research Group Sarawak (Dana RGS) UiTM Sarawak 2017 [600-UiTMKS (RMU. 5/2/RGS) (12/2019)].

\section{ETHICAL APPROVALS}

Not applicable.

\section{PUBLISHER'S NOTE}

This journal remains neutral with regard to jurisdictional claims in published institutional affiliation.

\section{REFERENCES}

Acharya J, Karak S, De B. Metabolite profile and bioactivity of Musa X paradisiaca L. flower extracts. J Food Biochem, 2016; 40:724-30. Adeolu AT, Enesi DO. Assessment of proximate, mineral, vitamin and phytochemical compositions of plantain (Musa paradisiaca) bract - an agricultural waste. Int Res J Plant Sci, 2013; 4:192-7.

Agatonovic-Kustrin S, Kustrin E, Morton DW. Phenolic acids contribution to antioxidant activities and comparative assessment of phenolic content in mango pulp and peel. S Afr J Bot, 2018; 116:158-63.

Arun KB, Madhavan A, Reshmita TR, Thomas S, Nisha P. Musa paradisiaca inflorescence induces human colon cancer cell death by modulating cascades of transcriptional events [10.1039/C7FO01454F]. Food Funct, 2018; 9(1):511-24.

Baskar R, Shrisakthi S, Sathyapriya B, Shyampriya R, Nithya R, Poongodi P. Antioxidant potential of peel extracts of banana varieties (Musa sapientum). Food Nutr Sci, 2011; 2:1128-33.

Buapool D, Mongkol N, Chantimal J, Roytrakul S, Srisook E, Srisook K. Molecular mechanism of anti-inflammatory activity of Pluchea indica leaves in macrophages RAW 264.7 and its action in animal models of inflammation. J Ethnopharmacol, 2013; 146:495-504.

Cao H, Chai TT, Wang X, Morais-Braga MFB, Yang JH, Wong FC, Wang R, Yao H, Cao J, Cornara L, Burlando B, Wang Y, Xiao J, Coutinho HDM. Phytochemicals from fern species: potential for medicine applications. Phytochem Rev, 2017; 16:379-440.

Chandra S, Khan S, Avula B, Lata H, Yang MH, Elsohly MA, Khan IA. Assessment of total phenolic and flavonoid content, antioxidant properties, and yield of aeroponically and conventionally grown leafy vegetables and fruit crops: a comparative study. Evid Based Complement Alternat Med, 2014; 2014:253875.

Chen BH, Hsieh CH, Tsai SY, Wang CY, Wang CC. Anticancer effects of epigallocatechin-3-gallate nanoemulsion on lung cancer cells through the activation of AMP-activated protein kinase signaling pathway. Sci Rep, 2020; 10:5163.

D'Amelia V, Aversano R, Chiaiese P, Carputo D. The antioxidant properties of plant flavonoids: their exploitation by molecular plant breeding. Phytochem Rev, 2018; 17(3):611-25.

Dahham S, Taleb-Agha M, Tabana Y, Abdul Majid AMS Antioxidant activities and anticancer screening of extracts from banana fruit (Musa sapientum). Acad J Cancer Res, 2015; 8:28-34.

Das A, Jayaprakash B, Deepesh P, Priya G, Soundariya S. In vitro anticancer study of bioactive compound isolated from Musa extract (Musa acuminata). Indian J Public Health Res Dev, 2020; 11:340.

Do QD, Angkawijaya AE, Tran-Nguyen PL, Huynh LH, Soetaredjo FE, Ismadji S, Ju YH. Effect of extraction solvent on total phenol content, total flavonoid content, and antioxidant activity of Limnophila aromatica. J Food Drug Anal, 2014; 22(3):296-302.

Du GJ, Zhang Z, Wen XD, Yu C, Calway T, Yuan CS, Wang CZ. Epigallocatechin gallate (EGCG) is the most effective cancer chemopreventive polyphenol in green tea. Nutrients, 2012; 4:1679-91.

Elancheran E, Jayamuthunagai J. Functional, Physicochemical and anti-oxidant properties of dehydrated banana blossom powder and its incorporation in biscuits. Int J Chemtech Res, 2014; 6:4446-54.

Fatma Sri W, Dini Hara T, Helmi A. Cytotoxicity study of ethanol extract of the leaves of Asam Kandis (Garcinia cowa Roxb.) on T47D breast cancer cell line. Phcog J, 2015; 7(6):369-71.

Francini-Pesenti F, Spinella P, Calò LA. Potential role of phytochemicals in metabolic syndrome prevention and therapy. Diabetes Metab Syndr Obes, 2019; 12:1987-2002.

Han SR, Kim KH, Kim HJ, Jeong SH, Oh TJ. Comparison of biological activities using several solvent extracts from Ramariabotrytis Indian J Sci Technol, 2016; 9(41):1-6.

Hussain S, Ashafaq M. Epigallocatechin-3-Gallate (EGCG): mechanisms, perspectives, and clinical applications in cervical cancer. J Cancer Prev Curr Res, 2018; 9(4):178-82.

Hwang JS, Lee B, An X, Jeong H, Kim YE, Lee I, Lee H, Kim DO. Total phenolics, total flavonoids, and antioxidant capacity in the 
leaves, bulbs, and roots of Allium hookeri. Korean J Food Sci Technol, 2015; 47:261-6.

Imam MZ, Akter S. Musa paradisiaca L. and Musa sapientum L.: a phytochemical and pharmacological review. J Appl Pharma Sci, 2011; 01(5):14-20.

Jawla S, Kumar Y, Khan MSY. Antimicrobial and antihyperglycemic activities of Musa paradisiaca flowers. Asian Pac J Trop Biomed, 2012; 2(2):914-8.

Johari M, Khong HY. Total phenolic content and antioxidant and antibacterial activities of Pereskia bleo. Adv Pharmacol Sci, 2019; 2019:1-4

Johnson AC. Is freshwater macroinvertebrate biodiversity being harmed by synthetic chemicals in municipal wastewater? Curr Opin Environ, 2019; 11:8-12.

Joseph J, Paul D, Kavitha MP, Kumar BD, Menon J, Bhat AR, Kumar KK. Preliminary phytochemical screening and in vitro antioxidant activity of banana flower (Musa paradisiaca AAB nendran variety). J Pharm Res, 2014; 8:144-7.

Kapinova A, Kubatka P, Golubnitschaja O, Kello M, Zubor P, Solar P, Pec M. Dietary phytochemicals in breast cancer research: anticancer effects and potential utility for effective chemoprevention. Environ Health Prev Med, 2018; 23:36.

Khennouf S, Amira S, Arrar L, Baghiani A. Effect of some phenolic compounds and quercus tannins on lipid peroxidation. World Appl Sci J, 2009; 8(9):1144-9.

Kris-Etherton PM, Hecker KD, Bonanome A, Coval SM, Binkoski AE, Hilpert KF, Griel AE, Etherton TD. Bioactive compounds in foods: their role in the prevention of cardiovascular disease and cancer. Am J Med, 2002; 113(9, Supplement 2):71-88.

Kruk I, Aboul-Enein HY, Michalska T, Lichszteld K, Kładna A. Scavenging of reactive oxygen species by the plant phenols genistein and oleuropein. Luminescence, 2005; 20(2):81-9.

Kumar KPS, Bhowmik DSD, Umadevi M. Traditional and medicinal uses of banana. J Pharmacogn Phytochem, 2012; 1:51-63.

Lafta, MH. Antioxidant activity of aqueous extract of plantain flower bract. Eur J Mol Clin Med, 2020; 7:413-7.

Mahmood A, Ngah N, Omar MN. Phytochemical constituent and antioxidant activities in Musa x paradisiaca flower. Eur J Sci Res, 2011; 66(2):311-8.

Marikkar N, Tan SJ, Salleh A, Azlan A, Shukri MAM. Evaluation of banana (Musa sp.) flowers of selected varieties for their antioxidative and anti-hyperglycemic potentials. Int Food Res J, 2016; 23(5):1988-95.

Mosmann T. Rapid colorimetric assay for cellular growth and survival: application to proliferation and cytotoxicity assays. J Immunol Methods, 1983; 65(1):55-63.

Muhamad N, Muhmed S, Yusoff M, Gimbun J. Influence of solvent polarity and conditions on extraction of antioxidant, flavonoids, and phenolic content from Averrhoa bilimbi. J Food Sci Eng, 2014; 4:255-60.

Muniraj N, Siddharth S, Sharma D. Bioactive compounds: multitargeting silver bullets for preventing and treating breast cancer. Cancers (Basel), 2019; 11(10):1563.

Nadumane VK, Timsina B. Anti-cancer potential of banana flower extract: an in vitro study. Bangladesh J Pharmacol, 2014; 9(4):628 35

Nawaz H, Aslam M, Muntaha S. Effect of solvent polarity and extraction method on phytochemical composition and antioxidant potential of corn silk. Free Radic Antioxid, 2019; 9:05-11.

Ngo Van T, Scarlett C, Bowyer M, Ngo P, Vuong Q. Impact of different extraction solvents on bioactive compounds and antioxidant capacity from the root of Salacia chinensis L. J Food Qual, 2017; 2017(1):1-8.

Nikoo M, Regenstein JM, Ahmadi GH. Antioxidant and antimicrobial activities of (-)-epigallocatechin-3-gallate (EGCG) and its potential to preserve the quality and safety of foods. Compr Rev Food Sci Food Saf, 2018; 17:732-53.

Nisha P, Mini S. In vitro antioxidant and antiglycation properties of methanol extract and its different solvent fractions of Musa paradisiaca L. (Cv. Nendran) inflorescence. Int J Food Prop, 2014; 17(2):399-409.

Nordin ZM, Abu Bakar I, Omar M, Mahmood A. Effect of consuming lactogenic biscuits formulated with banana (Musa x paradisiaca) flower flour on expressed breast milk (EBM) among lactating working women. Food Res, 2019; 4:294-300.

Padam BS, Tin HS, Chye FY, Abdullah MI. Banana by-products: an under-utilized renewable food biomass with great potential. J Food Sci Technol, 2014; 51(12):3527-45.

Pan MH, Lai CS, Dushenkov S, Ho CT. Modulation of inflammatory genes by natural dietary bioactive compounds. J Agric Food Chem, 2009; 57(11):4467-77.

Pereira VV, Borel CR, Silva RR. Phytochemical screening, total phenolic content, and antioxidant activity of Byrsonima species. Nat Prod Res, 2015; 29(15):1461-5.

Pyrzynska K, Pękal A. Application of free radical diphenylpicrylhydrazyl (DPPH) to estimate the antioxidant capacity of food samples. Anal Methods, 2013; 5(17):4288-95.

Singh NA, Mandal AKA, Khan ZA. Potential neuroprotective properties of epigallocatechin-3-gallate (EGCG). Nutr J, 2016; 15:60.

Singh V, Aggrawal V. Phytochemical analysis and in vitro antioxidant activities of leaves, stems, flowers, and roots extracts of Bougainvillea spectabilis Willd. Int J Green Pharm, 2018; 12: 278-284.

Sitthiya K, Devkota L, Sadiq MB, Anal AK. Extraction and characterization of proteins from banana (Musa sapientum L) flower and evaluation of antimicrobial activities. J Food Sci Technol, 2018; 55(2): $658-66$.

Sroka Z. 2005. Antioxidative and antiradical properties of plant phenolics. Z Naturforsch C J Biosci, 2005; 60(11-12):833-843.

Sumathy J. Anticancer activity of crude extract and carotenoid pigments from fruits. Eur J Pharm Med Res, 2018; 3:394-400.

Tanamatayarat P, Limtrakul P, Chunsakaow S, Duangrat C. Screening of some rubiaceous plant for cytotoxic activity against cervix carcinoma (KB-3-1) cell line. Thai J Pharm Sci, 2003; 27(3-4):167-72.

Tripathi KD. Essentials of medical pharmacology. New Dehli, India: Jaypee Brothers Medical Publishers (P) Limited2013., pp 696-7, 2013.

Us MR, Muhammad A, Mohd K. Phytochemical screening, total flavonoid, and phenolic content assays of various solvent extracts of tepa of Musa paradisiaca. Malays J Anal Sci, 2016; 20:1181-90.

Velmurugan, G. Gut microbiota in toxicological risk assessment of drugs and chemicals: the need of hour. Gut Microbes, 2018; 9:465-8.

Wakeel A, Jan SA, Ullah I, Shinwari ZK, Xu M. Solvent polarity mediates phytochemical yield and antioxidant capacity of Isatis tinctoria Peer J, 2019; 7:e7857.

Xiao J, Bai W. Bioactive phytochemicals. Crit Rev Food Sci Nutr, 2019; 59:827-9.

\section{How to cite this article:}

Ariffin MM, Khong HY, Nyokat N, Liew GM, Hamzah AS, Boonpisuttinant K. In vitro antibacterial, antioxidant, and cytotoxicity evaluations of Musa paradisiaca cv. Sekaki florets from Sarawak, Malaysia. J Appl Pharm Sci, 2021; 11(05): 091-099 